\title{
Alternaria toxins alternariol and alternariol monomethyl ether in grain foods in Canada
}

\author{
Peter M. Scott • Wendy Zhao • Sherry Feng • Benjamin P.-Y. Lau
}

Received: 21 June 2012 /Revised: 16 August 2012 / Accepted: 17 August 2012 / Published online: 4 September 2012

(C) The Author(s) 2012. This article is published with open access at Springerlink.com

\begin{abstract}
Alternaria alternata has been reported to be the most common fungus on Canadian Western wheat. The Alternaria toxins alternariol $(\mathrm{AOH})$ and alternariol monomethyl ether (AME) are mutagenic in vitro and there is also limited evidence for carcinogenic properties. They have been found in wheat from Europe, Argentina, China and Australia, but they have not been looked for in Canadian grains or grain foods. In the present study, 83 samples of grain-based food sold in Canada, including flour, bran, breakfast cereals, infant cereals and bread, were analysed for $\mathrm{AOH}$ and AME using extraction with methanol, cleanup on combined aminopropyl/C18 solid phase extraction (SPE) columns, and liquid chromatography (LC) with tandem mass spectrometric (MS/MS) determination. The overall average recoveries of $\mathrm{AOH}$ and AME from a variety of spiked cereal foods $(n=13)$ were $45 \pm 9 \%$ and $53 \pm 9 \%$, which could be attributed mainly to MS matrix effects The instrumental limits of detection (LOD) were $0.34 \mathrm{ng} / \mathrm{g}$ and $0.13 \mathrm{ng} / \mathrm{g}$ for $\mathrm{AOH}$ and AME, respectively, and the instrumental limits of quantitation (LOQ) were 1.1 and $0.43 \mathrm{ng} / \mathrm{g}$. Of 83 samples analysed, 70 were positive for $\mathrm{AOH}$ (up to $63 \mathrm{ng} / \mathrm{g}$, in a soft wheat bran) and 64 contained AME (up to $12 \mathrm{ng} / \mathrm{g}$ in a bran-based breakfast cereal). Of particular interest was the presence of $\mathrm{AOH}$ and/or AME in 27 out of $30 \mathrm{infant}$ foods (up to $4.4 \mathrm{ng} / \mathrm{g}$ and $9.0 \mathrm{ng} / \mathrm{g}$, respectively, in a sample of multigrain cereal).
\end{abstract}

Keywords Alternariol · Alternariol monomethyl ether . Liquid chromatography · Tandem mass spectrometry · Grain foods

P. M. Scott $(\bowtie) \cdot$ W. Zhao $\cdot$ S. Feng $\cdot$ B. P.-Y. Lau

Health Canada, Food Research Division,

251 Sir Frederick Banting Driveway,

Ottawa, ON K1A 0K9, Canada

e-mail: Peter_Scott@hc-sc.gc.ca

\section{Introduction}

Alternariol (AOH) and alternariol monomethyl ether (AME) are the main benzopyrone mycotoxins produced by Alternaria alternata. They were first isolated and structurally characterized as 3,7,9-trihydroxy-1-methyl-6H-dibenzo[b, $d$ ]pyran-6-one and 3,7-dihydroxy-9-methoxy-1-methyl$6 H$-dibenzo[b, $d]$ pyran-6-one, respectively, 60 years ago (Raistrick et al. 1953). Other species of Alternaria (Ostry 2008; Logrieco et al. 2009), Stagonospora nodorum (Tan et al. 2009) and Phomopsis strains (Abreu et al. 2012) have also been found to produce AOH and AME. The toxicological database on AOH and AME is limited. Although their acute toxicity in animals is low, they are mutagenic in vitro and there is also some evidence for carcinogenic properties in unconventional assays (Brugger et al. 2006; Ostry 2008; EFSA 2011): pre-cancerous changes were observed in the oesophageal mucosa of mice fed AME for 10 months (Yekeler et al. 2001); human embryo tissue treated with $\mathrm{AOH}$ caused subcutaneous induction of squamous cell carcinoma in mice (Liu et al. 1992); NIH/3T3 cells transformed by AME caused tumours subcutaneously in mice (Liu et al. 1991); and $\mathrm{AOH}$ and AME induced DNA strand breaks in cell cultures (Fehr et al. 2009).

Natural occurrences of AOH, AME, and in some cases other Alternaria toxins have been reported in various fruits, processed fruit products such as apple juice, tomato products, wheat and other grains, sunflower seeds, oilseed rape meal, flax seed, linseed and pecans (Ostry 2008; Logrieco et al. 2009). They have also been found in Canadian lentils (Ostry et al. 2004). Another Alternaria toxin, tenuazonic acid, was recently found in beer and other cereal foods (Siegel et al. 2010b; Asam et al. 2012). Currently, there are no regulations anywhere in the world for the presence of Alternaria toxins in food or feed. 
$\mathrm{AOH}$ and $\mathrm{AME}$ have been found in wheat from Europe, Russia, Kenya, Argentina, China and Australia (Gruber-Schley and Thalmann 1988; GrabarkiewiczSzczesna and Chelkowski 1993; Webley et al. 1997; Li and Yoshizawa 2000; Scott 2001; Müller et al. 2002; Azcarate et al. 2008; Ostry 2008; Logrieco et al. 2009; Burkin and Kononenko 2011; Wagacha et al. 2010). Alternaria alternata has been reported to be the most frequently isolated fungus from western Canadian wheat (Clear et al. 2005), but Alternaria toxins have not been looked for previously in Canadian grains or grainbased foods. $\mathrm{AOH}$ and $\mathrm{AME}$ were stable under wet baking conditions as in bread baking (Siegel et al. 2010a) so they might be expected to occur in Canadian grain-based foods. In fact the incidence of these mycotoxins in grain-based foods was low in European studies (Asam et al. 2011; EFSA 2011). The present report describes the use of liquid chromatography (LC)-tandem mass spectrometry (MS/MS) to survey Canadian grainbased foods for $\mathrm{AOH}$ and $\mathrm{AME}$.

$10 \mu \mathrm{L}$ Shredded Wheat

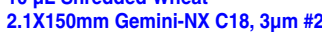

185 bar; cone $=75$; des $=750,350^{\circ}$; source $=140^{\circ}, 3 \mathrm{kV}$

06-Jun-2011 $A=100 \%$ H2O (LC-MS grade) $\mathrm{B}=100 \% \mathrm{MeOH}$
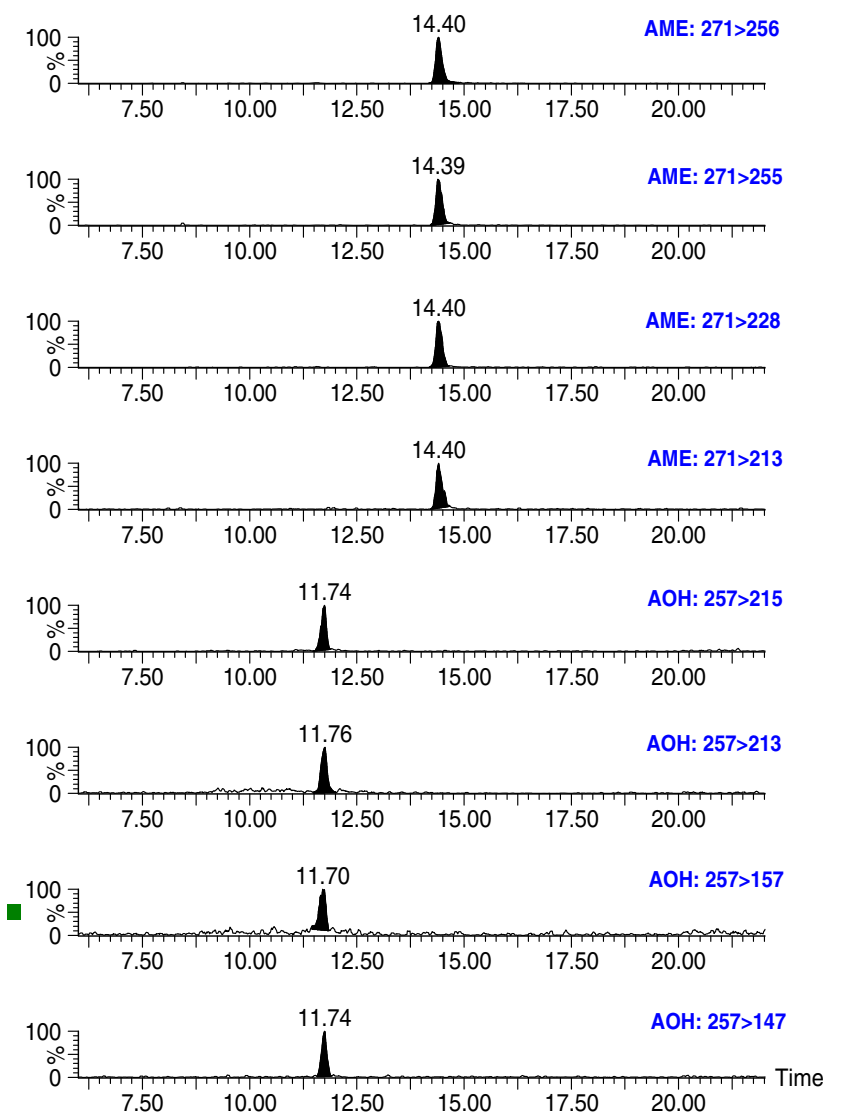

Fig. 1 LC-MS/MS analysis (using the Micromass Quattro Ultima) of AME $(9.0 \mathrm{ng} / \mathrm{g})$ and $\mathrm{AOH}(11 \mathrm{ng} / \mathrm{g})$ in a $100 \%$ whole grain shredded wheat sample
Table 1 Collision energies for $\mathrm{AOH}$ and AME MRM transitions on two instruments

\begin{tabular}{lcc}
\hline MRM transition & $\begin{array}{l}\text { Collision energy } \\
\text { (Premier), eV }\end{array}$ & $\begin{array}{l}\text { Collision energy } \\
\text { (Ultima), eV }\end{array}$ \\
\hline $257 \rightarrow 147$ & 32 & 32 \\
$257 \rightarrow 157$ & 30 & 25 \\
$257 \rightarrow 213$ & 23 & 25 \\
$257 \rightarrow 215$ & 25 & 25 \\
$271 \rightarrow 213$ & 35 & 37 \\
$271 \rightarrow 228$ & 30 & 27 \\
$271 \rightarrow 255$ & 32 & 30 \\
$271 \rightarrow 256$ & 22 & 20 \\
\hline
\end{tabular}

\section{Materials and methods}

Most samples were obtained from retail stores in Canada. They were ground if necessary, then each sample $(2.5 \mathrm{~g})$ was homogenized with $25 \mathrm{ml}$ extraction solvent (methanol), followed by centrifuging. Ten millilitres of water was added to $1 \mathrm{ml}$ extract and the mixture loaded onto a combined aminopropyl/C18 solid phase extraction (SPE) column (Sorbent Technologies, Atlanta, GA) previously conditioned with $5 \mathrm{ml}$ methanol and $5 \mathrm{ml}$ water. The column was washed with $3 \mathrm{ml} 35 \%$ acetonitrile and $3 \mathrm{ml}$ water. Toxins were eluted with $3 \mathrm{ml}$ acetonitrile-acetic acid $(100: 1, \mathrm{v} / \mathrm{v})$. The eluate was evaporated to dryness at $40-45{ }^{\circ} \mathrm{C}$ under nitrogen and the residue was dissolved in $500 \mu \mathrm{l}$ methanol (some residues from negative samples of wheat flour and wheat bran were dissolved in $200 \mu \mathrm{l})$, then filtered.

Table $2 \mathrm{AOH}$ and AME in flour and bran

\begin{tabular}{lll}
\hline Sample & AOH $(\mathrm{ng} / \mathrm{g})$ & AME $(\mathrm{ng} / \mathrm{g})$ \\
\hline Whole wheat flour & 0.5 & 0.5 \\
Hard wheat flour 1 & nd & nd \\
Hard wheat flour 2 & nd & nd \\
Hard wheat flour 3 & nd & nd \\
Soft wheat flour 1 & 0.5 & nd \\
Soft wheat flour 2 & nd & nd \\
Durum wheat flour & nd & nd \\
Durum wheat bran 1 & nd & nd \\
Durum wheat bran 2 & nd & nd \\
Durum wheat bran 3 & nd & nd \\
Hard wheat bran 1 & 6.0 & 1.0 \\
Hard wheat bran 2 & 2.1 & 2.5 \\
Soft wheat bran 1 & 3.0 & 2.5 \\
Soft wheat bran 2 & 63 & 8.9 \\
Soft wheat bran 3 & nd & nd \\
\hline
\end{tabular}

nd less than LOD 
Table $3 \mathrm{AOH}$ and AME in breakfast cereals

\begin{tabular}{lcc}
\hline Sample & $\begin{array}{l}\mathrm{AOH} \\
(\mathrm{ng} / \mathrm{g})\end{array}$ & $\begin{array}{r}\mathrm{AME} \\
(\mathrm{ng} / \mathrm{g})\end{array}$ \\
\hline Oats cereal & 1.0 & 1.0 \\
Oatmeal cereal & 0.8 & 0.8 \\
Wheat cereal & 2.5 & 3.0 \\
Ring-shaped cereal & 0.4 & 0.4 \\
Mixed cereal 1 & 0.6 & 0.4 \\
Mixed cereal 2 & 0.6 & 0.4 \\
Shredded wheat cereal 1 & 6.0 & 3.5 \\
Shredded wheat cereal 2 & 7.0 & 3.0 \\
100\% Whole grain shredded wheat cereal & 11 & 9.0 \\
100\% Bran cereal & 35 & 12 \\
\hline
\end{tabular}

LC-MS/MS was performed on a Waters Acquity UPLC with a Phenomenex (Torrance, CA, USA) Gemini-NX C18,

Table $4 \mathrm{AOH}$ and AME in bread

\begin{tabular}{|c|c|c|}
\hline Sample & $\mathrm{AOH}(\mathrm{ng} / \mathrm{g})$ & $\operatorname{AME}(n g / g)$ \\
\hline Sovital bread & 1.5 & 0.5 \\
\hline White bread 1 & 0.4 & nd \\
\hline White bread 2 & 0.5 & nd \\
\hline White bread 3 & 0.6 & nd \\
\hline White bread 4 & 0.6 & nd \\
\hline White bread 5 & 0.8 & 0.3 \\
\hline White bread 6 & 1.1 & 0.5 \\
\hline $60 \%$ Whole wheat bread & 5.0 & 2.1 \\
\hline $100 \%$ Whole grain wheat bread 1 & 2.6 & 1.3 \\
\hline $100 \%$ Whole grain wheat bread 2 & 3.0 & 1.0 \\
\hline $100 \%$ Whole wheat granola bread & 1.0 & nd \\
\hline $100 \%$ Whole wheat bread 1 & 0.7 & nd \\
\hline $100 \%$ Whole wheat bread 2 & 5.3 & 1.4 \\
\hline $100 \%$ Whole wheat bread 3 & 2.0 & 0.6 \\
\hline $100 \%$ Whole wheat bread 4 & 1.0 & 0.2 \\
\hline $100 \%$ Whole wheat bread 5 & 1.9 & 0.6 \\
\hline $100 \%$ Whole wheat bread 6 & 2.1 & 0.8 \\
\hline $100 \%$ Whole wheat bread 8 & 0.8 & nd \\
\hline Bran bread & 2.2 & 0.4 \\
\hline Rye bread 1 & 6.7 & 3.0 \\
\hline Rye bread 2 & 1.4 & 0.6 \\
\hline Rye bread 3 & 1.3 & 0.4 \\
\hline Rye bread 4 & 0.9 & 0.2 \\
\hline Rye bread 5 & 1.2 & 0.3 \\
\hline Multigrain bread 1 & 0.8 & 0.3 \\
\hline Multigrain bread 2 & 1.6 & 0.6 \\
\hline Multigrain bread 3 & 3.3 & 0.8 \\
\hline Multigrain bread 4 & 0.6 & 0.2 \\
\hline Cinnamon raisin bread & 1.1 & 0.3 \\
\hline
\end{tabular}

nd less than LOD
Table $5 \mathrm{AOH}$ and AME in infant foods

\begin{tabular}{lcc}
\hline Sample & AOH (ng/g) & AME (ng/g) \\
\hline Biscuits 1 & 1.1 & nd \\
Biscuits 2 & 1.2 & 1.0 \\
Teething biscuits 1 & nd & 0.9 \\
Teething biscuits 2 & 1.0 & 0.9 \\
Apple biscuits & 0.7 & 0.7 \\
Toddler biscuits & 0.6 & 0.7 \\
Cookies and biscuits & nd & 1.1 \\
Oatmeal cookies and biscuits & 0.7 & 0.8 \\
Graham cookies 1 & 0.8 & 0.7 \\
Graham cookies 2 & 1.3 & 0.9 \\
Graham cookies 3 & 1.4 & 0.9 \\
Crackers 1 & 1.1 & 0.9 \\
Crackers 2 & 1.2 & 0.9 \\
Graham crackers & nd & 0.7 \\
Wheat cereal & 0.6 & 0.5 \\
Wheat \& oat cereal & 0.6 & 0.7 \\
Wheat, honey \& flakes & 0.7 & 0.7 \\
Wheat biscuit cereal & 0.5 & 0.5 \\
Wheat, yogurt \& blueberry cereal & 0.8 & 0.7 \\
Wheat with mixed fruit cereal & 0.6 & 0.7 \\
Wheat and rice cereal & 0.5 & 0.6 \\
Rice cereal & 0.7 & 0.8 \\
Mixed grain with fruit cereal & 0.7 & 0.7 \\
Mixed cereal 1 & 0.7 & 0.9 \\
Mixed cereal 2 & 1.4 & 0.8 \\
Mixed cereal with fruits & 0.6 & 0.7 \\
Multigrain cereal 1 & 4.4 & \\
Mixed grain cereal & 1.9 & \\
Organic barley cereal & 0.7 & \\
\hline & & \\
\hline
\end{tabular}

$n d$ less than LOD

$2.0 \times 150-\mathrm{mm}, 3-\mu \mathrm{m}$ column at room temperature coupled to a Waters Quattro-Premier XE Triple Quadrupole mass spectrometer (Milford, MA, USA). Autosampler tray temperature was $5{ }^{\circ} \mathrm{C}$. The flow rate was $0.175 \mathrm{ml} / \mathrm{min}$. Injection volume was $10 \mu \mathrm{l}$. Mobile phases were: $A=100 \% \mathrm{H}_{2} \mathrm{O}$ and

Table 6 Summary of AOH and AME in grain foods

\begin{tabular}{lccccc}
\hline Sample group & $\mathrm{n}$ & $\begin{array}{l}\mathrm{AOH} \\
\text { positive }\end{array}$ & $\begin{array}{l}\text { AOH } \\
\text { range } \\
(\mathrm{ng} / \mathrm{g})\end{array}$ & $\begin{array}{l}\text { AME } \\
\text { positive }\end{array}$ & $\begin{array}{l}\text { AME } \\
\text { range } \\
\text { (ng/g) }\end{array}$ \\
\hline Flour, bran & 15 & 6 & $\mathrm{nd}-63$ & 5 & nd-8.9 \\
Breakfast cereal & 10 & 10 & $0.4-35$ & 10 & $0.4-12$ \\
Bread & 29 & 29 & $0.4-6.7$ & 22 & nd-3.0 \\
Infant food & 29 & 25 & $\mathrm{nd}-4.4$ & 27 & nd-9.0 \\
\hline
\end{tabular}

nd less than LOD 
Table 7 Recoveries of $\mathrm{AOH}$ and AME from different cereal food matrices ( \pm standard deviation)

\begin{tabular}{lllll}
\hline Matrix & $n$ & $\begin{array}{c}\text { Added } \\
\text { level (ng/g) }\end{array}$ & AOH (\%) & AME (\%) \\
\hline Whole-wheat flour & 3 & 10 & $35 \pm 6$ & $45 \pm 10$ \\
Wheat breakfast cereal & 3 & 10 & $40 \pm 2$ & $50 \pm 5$ \\
Hard wheat bran & 3 & 10 & $47 \pm 14$ & $52 \pm 8$ \\
Rice cereal & 3 & 10 & $49 \pm 3$ & $71 \pm 10$ \\
Wheat cereal & 3 & 10 & $58 \pm 2$ & $65 \pm 0.3$ \\
Biscuits & 3 & 10 & $56 \pm 3$ & $40 \pm 1$ \\
Organic barley baby cereal & 3 & 10 & $58 \pm 2$ & $53 \pm 4$ \\
$60 \%$ Whole-wheat bread & 3 & 10 & $34 \pm 4$ & $54 \pm 10$ \\
White bread & 3 & 10 & $38 \pm 8$ & $59 \pm 14$ \\
$100 \%$ Whole-grain-wheat bread & 3 & 10 & $44 \pm 9$ & $49 \pm 9$ \\
Bran bread & 3 & 10 & $32 \pm 6$ & $37 \pm 6$ \\
Rye bread & 3 & 10 & $49 \pm 5$ & $54 \pm 9$ \\
Cinnamon raisin bread & 3 & 10 & $45 \pm 5$ & $56 \pm 5$ \\
Average & & & $45 \pm 9$ & $53 \pm 9$ \\
\hline
\end{tabular}

$B=100 \%$ methanol with the following gradient: $30 \% \mathrm{~B}$ up to $6.0 \mathrm{~min}, 80 \% \mathrm{~B}$ from 6.0 to $17.0 \mathrm{~min}$, then $30 \% \mathrm{~B}$.

Alternatively, depending on instrument availability, LCMS/MS was carried out on an Agilent 1,200 liquid chromatograph coupled to a Micromass Quattro Ultima Triple Quadrupole MS/MS, using a Jones (Grace Davison, Discovery Sciences, USA) Genesis C18, $2.1 \times 150-\mathrm{mm}, 3-\mu \mathrm{m}$ column at $30{ }^{\circ} \mathrm{C}$ with a gradient system of $30-80 \%$ methanol in water similar to that above except staying at $80 \%$ methanol up to $18 \mathrm{~min}$.

Negative ion electrospray ionization MS/MS conditions included capillary voltage: $-3.0 \mathrm{kV}$, cone voltage $20 \mathrm{~V}$ (on the Ultima instrument) or $40 \mathrm{~V}$ (on the Premier instrument), source temperature $120{ }^{\circ} \mathrm{C}$ (Premier) or $140{ }^{\circ} \mathrm{C}$ (Ultima), desolvation temperature was $380{ }^{\circ} \mathrm{C}$ (Premier) or $350{ }^{\circ} \mathrm{C}$ (Ultima), cone gas $\left(\mathrm{N}_{2}\right)$ flow $50 \mathrm{l} / \mathrm{h}$, desolvation gas $\left(\mathrm{N}_{2}\right)$ flow $600 \mathrm{l} / \mathrm{h}$, collision gas (Ar) pressure $3.10 \times 10^{-3} \mathrm{mbar}$, multiplier voltage $625 \mathrm{~V}$ (Ultima) or $650 \mathrm{~V}$ (Premier). Multiple reaction monitoring (MRM) analysis (dwell time $0.080 \mathrm{~s}$ ) had four transitions per compound (see Fig. 1). Collision energies for each MRM transition are given in Table 1. Results for three transitions were averaged for the food analyses (Tables 2, 3, 4, 5 and 6).

The instrumental limits of detection (LOD) (based on $\mathrm{S} / \mathrm{N}$ ratio $=3$ ) for $\mathrm{AOH}$ and $\mathrm{AME}$ were determined using the weakest response among the three MRM transitions for $\mathrm{AOH} \mathrm{(m/z} 257 \rightarrow 215 ; \mathrm{m} / \mathrm{z} 257 \rightarrow 213 ; \mathrm{m} / \mathrm{z} 257 \rightarrow 147)$ and for AME (m/z $271 \rightarrow 256 ; \mathrm{m} / \mathrm{z} 271 \rightarrow 255 ; \mathrm{m} / \mathrm{z} 271 \rightarrow 228)$. A positive result implies the presence of positive responses from all three MRM transitions at the same correct retention time of the analyte. The instrumental limits of quantitation (LOQ) were defined as 3.3-times the instrumental LOD. The overall method LOQ would be higher if extraction and clean-up recoveries and matrix effect were to be factored in. To determine matrix effects, $\mathrm{AOH}$ and $\mathrm{AME}$ standards equivalent to $20 \mathrm{ng} / \mathrm{g}$ grain food were added in $50 \%$ acetonitrile to extracts of whole wheat flour and four other grain foods before LC-MS/MS injection. The matrix effect was then calculated as the ratio (expressed in percentage) between the response of the analyte in the spiked sample to that of the same amount of standard in solvent, after the correction for the background level in the blank matrix (if present).

Overall method recoveries were determined in triplicate by spiking samples of grain food in which $\mathrm{AOH}$ and $\mathrm{AME}$ were not detected or if they were, their concentrations were subtracted from those determined in the spiked samples.

\section{Results and discussion}

As LC-UV was insufficiently sensitive at low ng/g levels, LCMS/MS was used for quantitation of $\mathrm{AOH}$ and AME in extracts of the 83 cereal foods analysed. The limits of detection (LOD) were $0.34 \mathrm{ng} / \mathrm{g}$ and $0.13 \mathrm{ng} / \mathrm{g}$ for $\mathrm{AOH}$ and AME, respectively, and the limits of quantitation (LOQ), defined as

Table 8 LC-MS/MS matrix effects

\begin{tabular}{lcc}
\hline Extract & $\begin{array}{l}\text { AOH } \\
\text { recovery (\%) }\end{array}$ & $\begin{array}{l}\text { AME } \\
\text { recovery (\%) }\end{array}$ \\
\hline Blank & 100 & 100 \\
Whole-wheat flour $(n=3)$ & 59 & 53 \\
Oatmeal cereal $(n=2)$ & 67 & 104 \\
Whole-wheat bread $(n=1)$ & 84 & 110 \\
White bread $(n=2)$ & 88 & 98 \\
Hard wheat bran $(n=2)$ & 40 & 50 \\
\hline
\end{tabular}


3.3-times the LOD, were 1.1 and $0.43 \mathrm{ng} / \mathrm{g}$, respectively. The instrumental LODs obtained from the Ultima LC-MS/MS system $(0.33 \mathrm{ng} / \mathrm{g})$ for $\mathrm{AOH}$ and $0.13 \mathrm{ng} / \mathrm{g}$ for AME) were almost identical to those obtained from the Quattro-Premier LC-MS/MS system $(0.34 \mathrm{ng} / \mathrm{g}$ for $\mathrm{AOH}$ and $0.13 \mathrm{ng} / \mathrm{g}$ for AME). For this reason, a single value of LOD was used for each analyte.

LC-MS/MS has been used in two previous publications for determination of AOH and AME in grain foods (Siegel et al. 2010a; Asam et al. 2011). We found overall method recoveries of $\mathrm{AOH}$ and $\mathrm{AME}$ from 13 foods averaged 45 and $53 \%$, respectively, ranging from $32 \%$ (bran bread) to $58 \%$ (wheat and barley infant cereals) for $\mathrm{AOH}$ and $37 \%$ (bran bread) to $71 \%$ (rice cereal) for AME (Table 7). LCMS/MS matrix effects were determined for five foods. Signals of standard $\mathrm{AOH}$ and $\mathrm{AME}$ in the whole wheat flour extract averaged $59 \%$ and $53 \%$, respectively, compared with the standards in $50 \%$ acetonitrile (Table 8); for hard wheat bran the signal suppression averaged $40 \%$ and $50 \%$. Extracts of oatmeal cereal, whole wheat bread and white bread showed signal enhancement for AME. The overall method recoveries could be attributed to matrix effects (Table 8) in two cases where comparisons with overall method recoveries were made (whole wheat flour and hard wheat bran). Unfortunately, $\left[{ }^{13} \mathrm{C}\right]$-labelled $\mathrm{AOH}$ and AME were not available for use as internal standards in a stable isotope dilution assay (SIDA).

$\mathrm{AOH}$ and $\mathrm{AME}$ were found in a wide range of grain foods grouped into flour and bran, breakfast cereals, bread, and infant foods (Tables 2, 3, 4, 5 and 6). A reliable comparison between food types is not possible considering the small number of samples in most cases (e.g. only one rice cereal and one barley cereal were analysed in the infant foods group). Concentrations of $\mathrm{AOH}$ and AME found in the grain foods were not corrected for the overall average method recoveries as an $F$-test showed that recovery variances for 13 different matrices (Table 7) were not uniform. It is noteworthy that $\mathrm{AOH}$ and/or AME were detected in 25 out of 29 infant foods (up to $4.4 \mathrm{ng} / \mathrm{g}$ and $9.0 \mathrm{ng} / \mathrm{g}$, respectively, in a sample of multigrain cereal) (Table 5).

Compared with surveys on grains themselves, there are few other surveys in the literature for $\mathrm{AOH}$ and/or AME in grain foods (Siegel et al. 2010a; Asam et al. 2011; EFSA 2011). In the EFSA's recent scientific opinion on Alternaria toxins in feed and food, maximum concentrations of $\mathrm{AOH}$ and AME in the Grains and grain-based products food category were reported to be $256 \mathrm{ng} / \mathrm{g}$ and $86 \mathrm{ng} / \mathrm{g}$, respectively (EFSA 2011). Mean concentrations for lower and upper bound estimates ranged from 1.8 to $7.3 \mathrm{ng} / \mathrm{g}$ for $\mathrm{AOH}$ and from 0.37 to $1.99 \mathrm{ng} / \mathrm{g}$ for AME. The EFSA noted that concentrations in grain milling products were generally lower in comparison with the grains themselves. Levels and incidences were extremely low and no toxins were detected in 49 samples of foods for infants and small children (the type was not specified) (EFSA 2011). However, the EFSA detection limits (for all foods) varied from 0.01 to $6.0 \mathrm{ng} / \mathrm{g}$ for both $\mathrm{AOH}$ and AME, with the median detection limit for each being $6.0 \mathrm{ng} / \mathrm{g}$ and $1.0 \mathrm{ng} / \mathrm{g}$, respectively (EFSA 2011). Siegel et al. (2010a) found $<15 \mathrm{ng} / \mathrm{g}$ of AME in a sample of buckwheat cookies (we did not analyse any buckwheat products) and Asam et al. (2011) detected $4.1 \mathrm{ng} \mathrm{AOH} / \mathrm{g}$ in a sample of spelt flour and AME in two samples of oat flakes for human consumption $(<1 \mathrm{ng} / \mathrm{g})$; levels of $\mathrm{AOH}$ and AME in our single samples of oats cereal and oatmeal cereal were also very low (Table 3 ).

Acknowledgments We thank Adam Becalski, Tony Zhao and Keri Kwong for providing the samples of grain foods, Jie Zhang for preliminary LC-MS work, and Stephen Hayward and Cunye Qiao for statistical advice.

\section{Conflict of interest None.}

Open Access This article is distributed under the terms of the Creative Commons Attribution License which permits any use, distribution, and reproduction in any medium, provided the original author(s) and the source are credited.

\section{References}

Abreu LM, Costa SS, Pfenning LH, Takahashi JA, Larsen TO, Anderson B (2012) Chemical and molecular characterization of Phomopsis and Cytospora-like endophytes from different host plants in Brazil. Fungal Biol 116:249-260

Asam S, Konitzer K, Rychlik M (2011) Determination of the Alternaria toxins alternariol and alternariol monomethyl ether in cereal, fruit and vegetable products using stable isotope dilution assays. Mycotox Res 27:23-28

Asam S, Lichtenegger M, Liu Y, Rychlik M (2012) Content of the Alternaria mycotoxin tenuazonic acid in food commodities determined by stable isotope dilution assay. Mycotox Res 28:9-15

Azcarate MP, Patriarca A, Terminiello L, Pinto VF (2008) Alternaria toxins in wheat during the 2004 to 2005 Argentinean harvest. J Food Prot 71:1262-1265

Brugger EM, Wagner J, Schuhmacher DM, Koch K, Podlech J, Metzler M, Lehmann L (2006) Mutagenicity of the mycotoxin alternariol in cultured mammalian cells. Toxicol Lett 164:221230

Burkin AA, Kononenko GP (2011) Enzyme immunoassay of alternariol for the assessment of risk of agricultural products contamination. Appl Biochem Microbiol 47:72-76

Clear RM, Patrick SK, Gaba D, Abramson D, Smith DM (2005) Prevalence of fungi and fusariotoxins in hard red spring and amber durum wheat seed from Western Canada, 2000 to 2002. Can J Plant Pathol 27:528-540

European Food Safety Authority (EFSA) (2011) Scientific opinion on the risks for animal and public health related to the presence of Alternaria toxins in feed and food. EFSA J 9:2407-2504

Fehr M, Pahlke G, Fritz J, Christensen MO, Boege F, Altemöller M, Podlech J, Marko D (2009) Alternariol acts as a topoisomerase poison, preferentially affecting the II $\alpha$ isoform. Mol Nutr Food Res 53:441-451 
Grabarkiewicz-Szczesna J, Chelkowski J (1993) Occurrence of Alternaria mycotoxins in wheat and triticale grain with "black point" injuries. Microbiol Alim Nutr 11:183-185

Gruber-Schley S, Thalmann A (1988) Zum Vorkommen von Alternaria spp. und deren Toxine in Getreide und mögliche Zusammenhänge mit Leistungsminderungen landwirtschaftlicher Nutztiere. Landwirtschaft Forsch 41:11-29

Li FQ, Yoshizawa T (2000) Alternaria mycotoxins in weathered wheat from China. J Agric Food Chem 48:2920-2924

Liu GT, Qian YZ, Zhang P, Dong ZM, Shi ZY, Zhen YZ, Miao J, Xu YM (1991) Relationships between Alternaria alternata and oesophageal cancer. In: O'Neill IK, Chen J, Bartsch H (eds) Relevance to human cancer of $\mathrm{N}$-nitroso compounds, tobacco smoke and mycotoxins. IARC, Lyon, pp 258-262

Liu GT, Qian YZ, Zhang P, Dong WH, Qi YM, Guo HT (1992) Etiologic role of Alternaria alternata in human esophageal cancer. Chin Med J 105:394-400

Logrieco A, Moretti A, Solfrizzo M (2009) Alternaria toxins and plant diseases: an overview of origin and occurrence. World Mycotox J 2:129-140

Müller M, van den Waydbrink G, Peters M, Umann K, Seyfarth W (2002) Belastung von Winterweizen mit Alternaria-Mykotoxinen in Land Brandenburg. Mycotox Res 18A:217-220

Ostry V (2008) Alternaria mycotoxins: an overview of chemical characterization, producers, toxicity, analysis and occurrence in foodstuffs. World Mycotox J 1:175-188

Ostry V, Skarkova, J, Ruprich, J (2004) Occurrence of Alternaria mycotoxins and Alternaria spp. in lentils and human health.
Abstracts 26th Mykotoxin-Workshop, Herrsching, Germany, May 17-19, 2004, p 87

Raistrick H, Stickings CE, Thomas R (1953) Studies in the biochemistry of micro-organisms. 90. Alternariol and alternariol monomethyl ether, metabolic products of Alternaria tenuis. Biochem J 55:421-433

Scott PM (2001) Analysis of agricultural commodities and foods for Alternaria mycotoxins. J AOAC Int 84:1809-1817

Siegel D, Feist M, Proske M, Koch M, Nehls I (2010a) Degradation of the Alternaria mycotoxins alternariol, alternariol monomethyl ether, and altenuene upon bread baking. J Agric Food Chem 58:9622-9630

Siegel D, Merkel S, Koch M, Nehls I (2010b) Quantification of the Alternaria mycotoxin tenuazonic acid in beer. Food Chem 120:902-906

Tan K-C, Trengove RD, Maker GL, Oliver RP, Solomon PS (2009) Metabolite profiling identifies the mycotoxin alternariol in the pathogen Stagonospora nodorum. Metabolomics 5:330-335

Wagacha JM, Steiner U, Dehne H-M, Zuehlke S, Spiteller M, Muthomi J, Oerke E-C (2010) Diversity in mycotoxins and fungal species infecting wheat in Nakuru District, Kenya. J Phytopathol 158:527-535

Webley DJ, Jackson KL, Mullins JD, Hocking AD, Pitt JI (1997) Alternaria toxins in weather-damaged wheat and sorghum in the 1995-1996 Australian harvest. Aust J Agric Res 48:1249-1255

Yekeler H, Bitmis K, Özcelik N, Doymaz M, Calta M (2001) Analysis of toxic effects of Alternaria toxins on esophagus of mice by light and electron microscopy. Toxicol Pathol 29:492-497 